\title{
Expression of nuclear pore protein POM121 in childhood acute leukemias and its relationship with prognosis
}

\author{
burcu genc cavlak ${ }^{1}$, ayse ozkan ${ }^{1}$, Ibrahim Bayram ${ }^{1}$, Gulay Sezgin ${ }^{1}$, Serhan Küpeli ${ }^{1}$, and \\ Atila Tanyeli ${ }^{1}$ \\ ${ }^{1}$ Cukurova University Faculty of Medicine
}

October 15, 2020

\begin{abstract}
Purpose:Nuclear pore complexes are a large group of proteins responsible for molecular passages between the cytoplasm and the nucleus. We aimed to investigate the status of POM121 gene expression, which is one of the nuclear pore proteins in childhood acute leukemias, compared with the normal population, and its relationship with prognosis and other clinical findings. Methods:Fifty-nine patients with ALL and 21 patients with AML, followed up and treated between January 2008 and November 2013, and 36 control subjects were included in the study. A real-time PCR method was used to detect POM121 gene expressions. Results:The mean value of POM121 expression was $3.75 \pm 2.91$ in ALL patients, $5.79 \pm 7.04$ in AML patients, and $3.32 \pm 3.76$ in the control group. POM121 expression was markedly higher in AML patients, but there was no statistically significant difference compared with the control group and ALL patients. Overall survival (OS) results were better in patients with lower POM121 expression than the mean of the control group among ALL and AML patients. However, the results were not statistically significant. Among ALL patients, patients with a higher POM121 expression than the mean of the control group, patients who had relapse and central nervous system involvement, patients who were in the standard risk group and without thrombocytopenia had statistically significantly lower OS results in the 3rd and 10th years. Conclusions:This is the first study in the literature to show the relationship between POM121 expression and prognosis in childhood leukemias, and this will be clarified further with more comprehensive studies.
\end{abstract}

Expression of Nuclear Pore Protein POM121 in Childhood Acute Leukemias and its Relationship with Prognosis

Burcu Genç Cavlak ${ }^{1}$, Ayşe Özkan ${ }^{1}$, İbrahim Bayram ${ }^{1}$, Gülay Sezgin ${ }^{1}$, Serhan Küpeli ${ }^{1}$, Atila Tanyeli ${ }^{1}$.

${ }^{1}$ Çukurova University Faculty of Medicine, Pediatric Oncology and Pediatric Bone Marrow Transplantation Unit, Adana, Turkey.

Correspondence:

Dr. Ayşe Özkan

Çukurova University Faculty of Medicine

Pediatric Oncology and Pediatric Bone Marrow Transplantation Unit

ADANA/TURKEY

Tel: $(+90-322) 3386060 / 3829$

e-mail: drayseozkan79@yahoo.com.tr 
We confirm that there are no prior publications or submissions with any overlapping information; there is no potential conflict of interest, real or perceived; each author listed on the manuscript has seen and approved the submission of this version of the manuscript and takes full responsibility for the manuscript.

Word count for abstract: 247

Word count for main text : 2726 word.

Table captions

Table 1. POM121 expression in ALL and AML patients and its relationship with certain clinical and laboratory findings.

Table 2. POM121 expression in ALL patients.

Table 3. POM121 expression compared with the control group and the effect of clinical and laboratory characteristics on overall survival in ALL patients.

Figure captions

Figure 1. Overall survival of acute lymphoblastic leukemia (ALL) patients

Figure 2. Overall survival of acute myeloblastic leukemia (AML) patients

Figure 3. Overall survival of B-acute lymphoblastic leukemia (B-ALL) patients

Figure 4. Overall survival of T-acute myeloblastic leukemia (T-ALL) patients

KEYWORDS: Acute leukemia, POM121 expression, prognosis

A short running title : Expression of POM121 in Childhood Acute Leukemias

Recommended reviewers:

Dr. Elvan Çağlar Çıtak

Mersin University Faculty of Medicine

Pediatric Hematology and Oncology

Tlf: +905053190251

e-mail:caglarcitak@mersin.edu.tr

Dr. Savaş Kansoy

Ege University Faculty of Medicine

Pediatric Hematology and Oncology

Tlf: +905322674610

e-mail:savaş.kansoy@ege.edu.tr

Dr. Elif Güler

Akdeniz University Faculty of Medicine

Pediatric Hematology and Oncology

Tlf: +90 5325639172

e-mail: elifguler@akdeniz.edu.tr

Abbreviations 


\begin{tabular}{ll}
\hline$A L L$ & acute lymphoblastic leukemia \\
\hline$A M L$ & acute myeloblastic leukemia \\
$C D$ & cluster of differentiation \\
$C N S$ & central nervous system \\
$H R G$ & high risk group \\
$M R G$ & risk group \\
SRG & standard risk group \\
$N P C$ & nuclear pore complexes \\
OS & overall survival \\
$B-A L L$ & B-acute lymphoblastic leukemia \\
$T-A L L$ & T-acute lymphoblastic leukemia \\
\hline
\end{tabular}

\section{Hosted file}

PBC MAIN TEXT.pdf available at https://authorea.com/users/367466/articles/486876-expressionof-nuclear-pore-protein-pom121-in-childhood-acute-leukemias-and-its-relationship-withprognosis

\section{Hosted file}

Table 1.pdf available at https://authorea.com/users/367466/articles/486876-expression-ofnuclear-pore-protein-pom121-in-childhood-acute-leukemias-and-its-relationship-withprognosis

\section{Hosted file}

Table 2.pdf available at https://authorea.com/users/367466/articles/486876-expression-ofnuclear-pore-protein-pom121-in-childhood-acute-leukemias-and-its-relationship-withprognosis

\section{Hosted file}

Table 3.pdf available at https://authorea.com/users/367466/articles/486876-expression-ofnuclear-pore-protein-pom121-in-childhood-acute-leukemias-and-its-relationship-withprognosis 
Figure 1

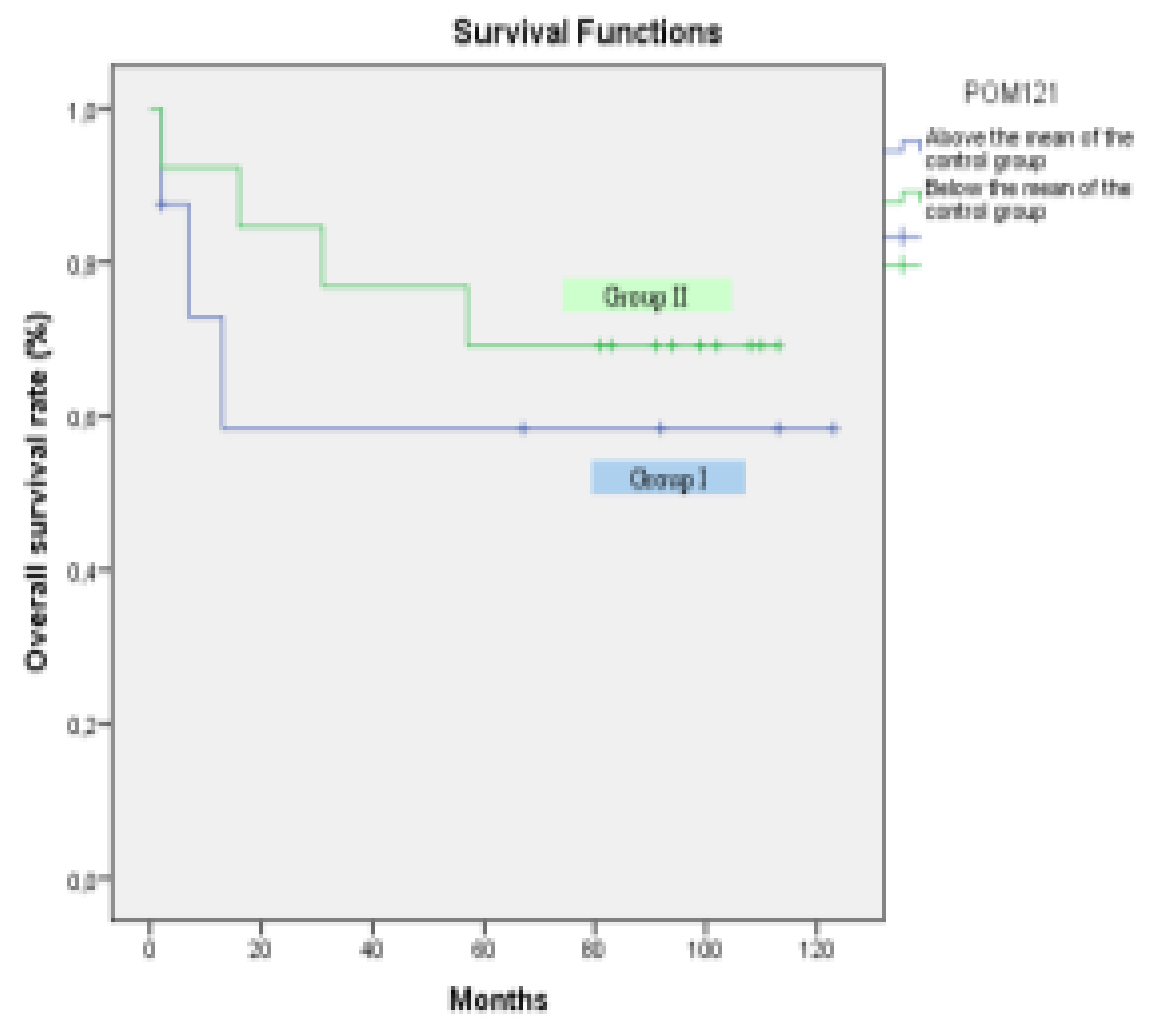


Figure 2

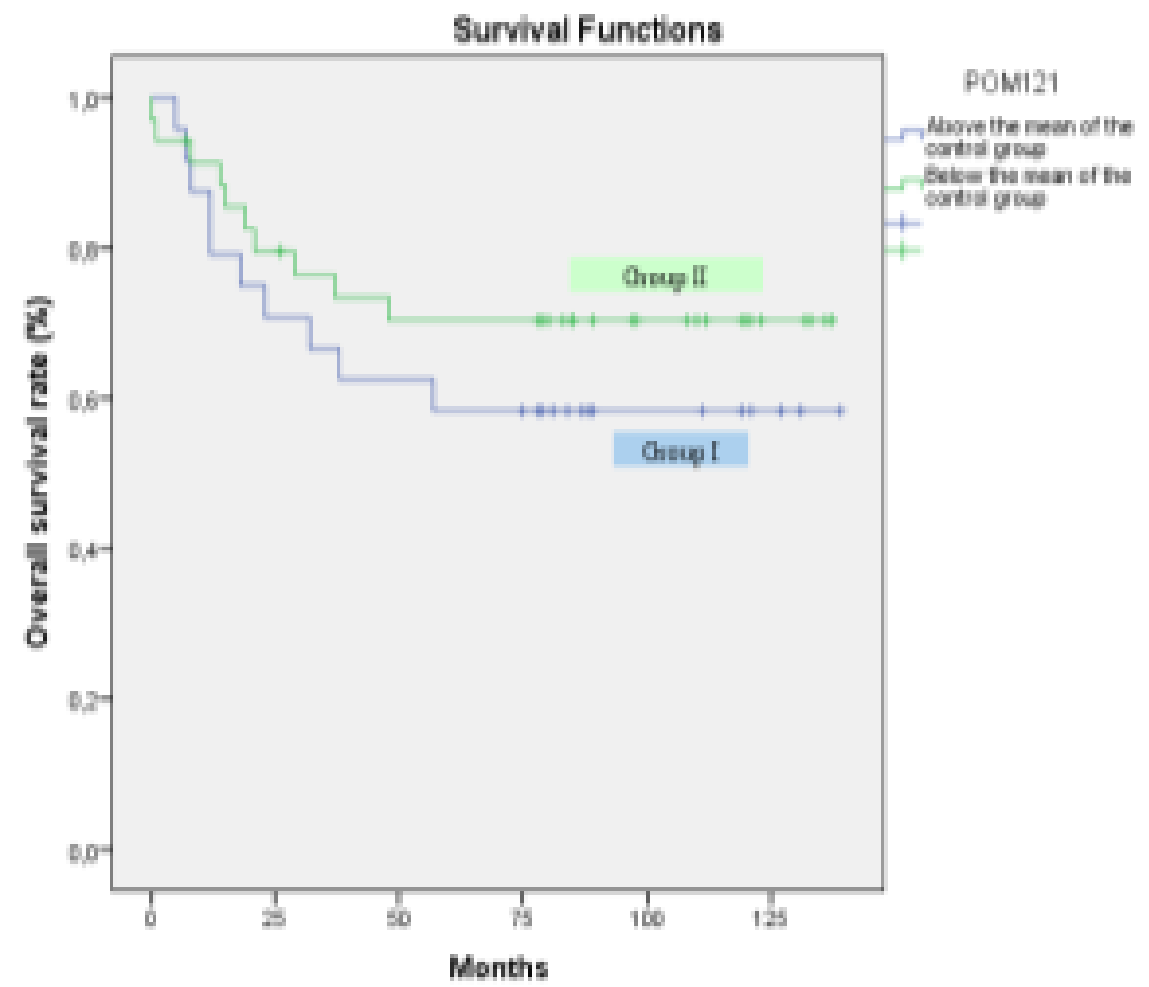


Figure 3

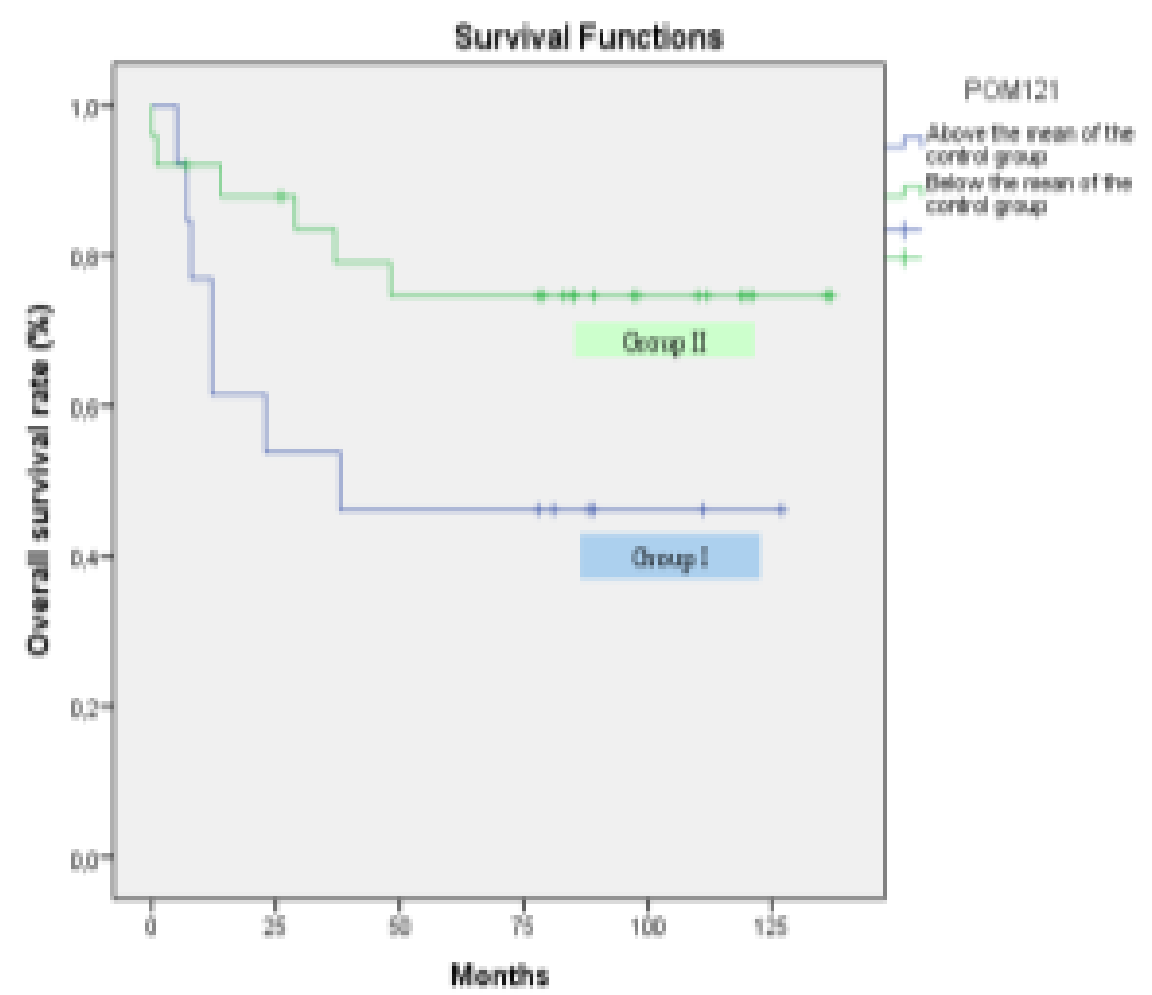


Figure 4

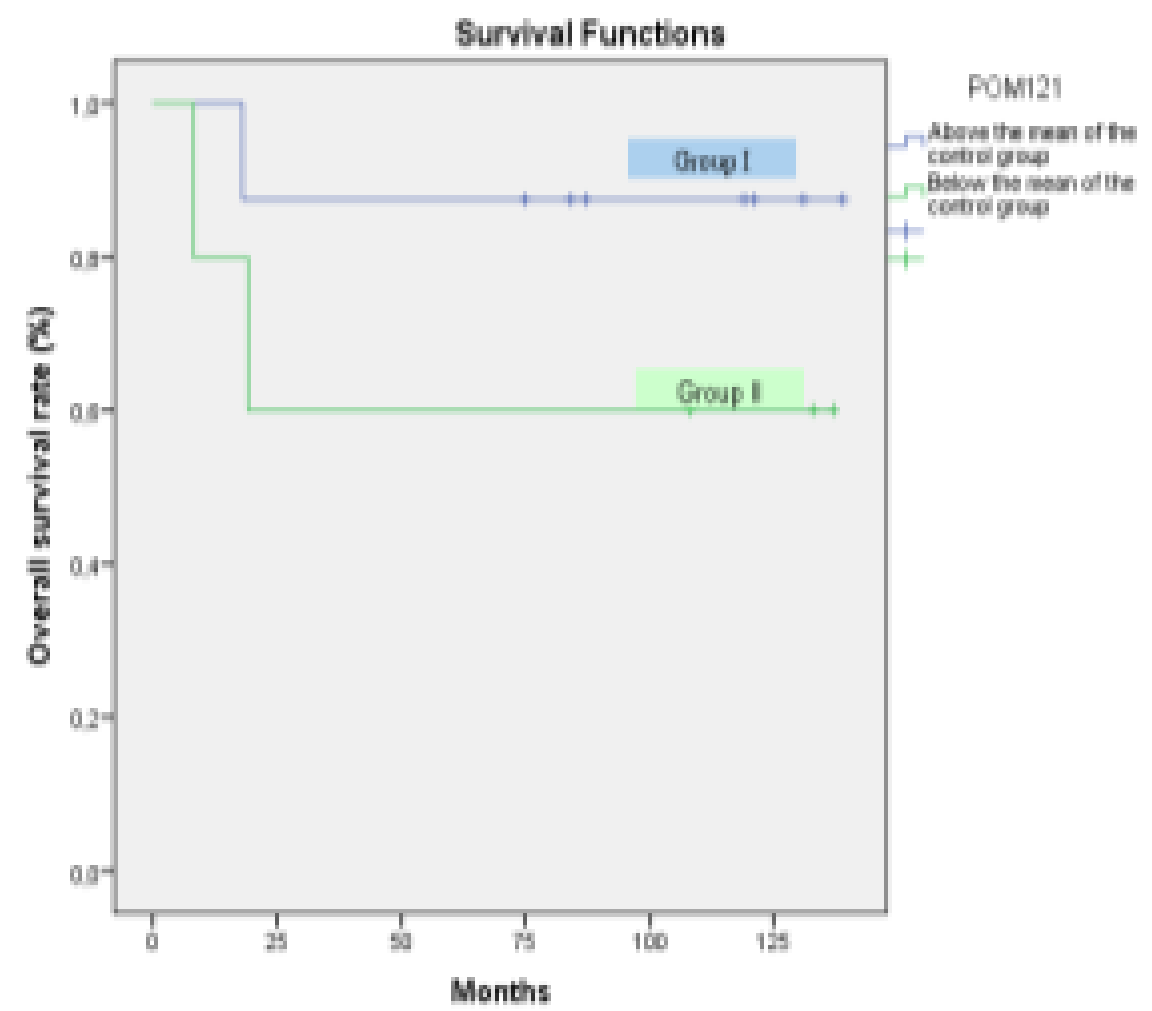

